\title{
Erfarenheter av rasifiering hos adopterade och adoptivföräldrar. Om betydelsen av ett icke-vitt utseende i den svenska vardagen
}

\author{
TOBIAS HÜBINETTE \& CARINA TIGERVALL
}

Denna artikel redovisar delar av en studie baserad på samtal med adopterade och adoptivföräldrar rörande deras erfarenheter av diskriminering utifrän ett annorlunda utseende. Materialet visar att de adopterades icke-vita kroppar hela tiden görs signifikanta i vardagen, vilket indikerar att ett icke-vitt utseende fortfarande tillskrivs en stor betydelse i ett samtida Sverige.

Det finns idag en växande kunskap om att människor med utländsk bakgrund särbehandlas negativt i det svenska samhället. Den rådande bilden av Sverige som ett icke-rasistiskt land har därmed kommit att utmanas av den nya diskrimineringsforsk-

Tobias Hübinette, fil.dr. i koreanologi, forskare vid Mångkulturellt centrum, Botkyrka

Carina Tigervall, fil.dr. i sociologi, forskare vid Centrum för genusvetenskap, Lunds unversitet ning som växt fram under de senaste åren. ${ }^{1}$ När denna särbehandling diskuteras fram-

1 För exempel på denna nya svenska diskrimineringsforskning, se bl.a. Paul Lappalainens utredning om strukturell diskriminering (SOU 2005:56), slutbetänkandet av den av Masoud Kamali ledda Utredningen om makt, integration och strukturell diskriminering samt de 13 rapporter som ingick i denna (SOU 2006:79) och Burns, Machado, Hellgren \& Bodin (red.) (2007). 
hålls ofta de utsattas kulturella, språkliga och religiösa skillnader gentemot majoritetsbefolkningen, då dessa faktorer antas spela en avgörande roll för att de drabbade marginaliseras. Andra sätt att förklara denna diskriminering på är att göra det i termer av klass och socioekonomiska faktorer. Ytterligare en förklaringsmodell är den som benämns strukturell diskriminering, det vill säga att fokusera på den roll som samhällsstrukturer och offentliga institutioner spelar. Denna nya diskrimineringsforskning kompletterar numera IMER-forskningen om internationell migration och etniska relationer, inom vilken migranters och deras barns utanförskap traditionellt har tolkats som ett resultat av deras bristande integration i majoritetssamhället.

Den aspekt som dock fortfarande sällan berörs när diskriminering diskuteras och studeras i en svensk kontext är utseendets roll, vilket antas vara av underordnad eller ingen betydelse. Att icke-vita människors icke-normativa kroppar i relation till den vita majoritetsbefolkningen ändå kan ha betydelse för diskriminering, är något som få vill kännas vid och tala om. När särbehandling enbart förstås med kulturella, sociala eller institutionella faktorer utesluts denna form av diskriminering. Det är detta osynliggörande av och denna tystnad kring diskriminering på grund av ett ickevitt utseende som vi syftar till att råda bot på med vår studie.

Föreliggande artikel redovisar några centrala resultat från vårt forskningsprojekt Adoption, diskriminering och etnisk identitet som bygger på intervjuer med 20 vuxna utlandsadopterade och åtta adoptiv- föräldrar med utlandsfödda barn. ${ }^{2}$ Adopterade och adoptivfamiljer kan betraktas som den mest ideala gruppen att studera för att undersöka diskriminering baserad på utseende, eftersom adopterade växer upp i svenska familjer och följaktligen måste betraktas som etniskt-kulturellt svenska. Utlandsadopterade är framför allt den enda demografiska subkategori av första generationens icke-vita invandrare, vilka delar socioekonomiska förhållanden med den mest privilegierade delen av den vita majoritetsbefolkningen i Sverige. Studien syftar vidare till att bidra till en förståelse av adoptivföräldrars roll, vilken aldrig tidigare blivit belyst inom forskningen, och därför undersöks även adoptivföräldrars erfarenheter av diskriminering gentemot familjen och barnen.

Svensk adoptionsforskning har huvudsakligen koncentrerat sig på att undersöka utlandsadopterades anknytning till adoptivfamiljen under barndomen, medan svensk IMER-forskning har fokuserat grupper med utländsk bakgrund som i första hand särskiljer sig etniskt-kulturellt från majoritetsbefolkningen. Det saknas därför kvalitativ forskning om vuxna adopterades situation, liksom studier av adoption och adoptivfamiljer i relation till frågor som rör migration och diskriminering. I denna studie möts den nya svenska adoptionsforskningen och den nya svenska diskrimineringsforskningen med utgångspunkten att adopterades och adoptivföräldrars upplevelser kan bidra med kunskap om hur sär-

2 Forskningsprojektet finansieras av FAS, Forskningsrådet för arbetsliv och socialvetenskap, och löper under åren 2007-08.

Tobias Hübinette \& Carina Tigervall: Erfarenheter av rasifiering hos adopterade... 
behandling utifrån ett icke-vitt utseende verkar i praktiken på en vardaglig nivå i ett samtida Sverige.

\section{Forskningsområde}

Totalt har 50000 utlandsfödda barn adopterats till landet under en 50-årsperiod, och Sverige är det land i världen som adopterat mest internationellt i förhållande till den infödda befolkningen. År 2000 var 62 procent kvinnor och 38 procent män av den utlandsadopterade vuxenpopulationen över 25 år, och av dessa var 51 procent av kvinnorna och 29 procent av männen födda i Korea (Rooth 2001). År 2006 var Kina det vanligaste födelselandet bland de utlandsfödda adoptivbarnen i åldrarna 0-14 år, och Indien för dem mellan 15 och 29 år, medan Korea dominerade åldersgruppen 30-44 år (Bernhardtz \& Klintefelt 2007). De internationellt adopterande föräldrarna kännetecknas slutligen av att en hög andel tillhör de övre samhällsskikten med avseende på utbildnings- och inkomstnivå (Reuterberg \& Hansen 2001).

Adoptionsforskningen har i Sverige liksom överhuvudtaget i västvärlden dominerats av psykologer och medicinare och har i första hand studerat adopterade som barn och ungdomar och deras anknytning och anpassning till adoptivfamiljen. Svensk adoptionsforskning tenderar generellt att fokusera på uppväxten och familjen framför vuxenlivet och samhället, och dessutom saknas med få undantag forskning om adoptivföräldrar och deras erfarenheter. Den dominerande adoptionsforskningen har därför sällan eller aldrig intres- serat sig för vuxna adopterades situation, och än mindre för deras erfarenheter av att behandlas annorlunda utifrån frågor rörande diskriminering på en samhällelig nivå.

Vår studie relaterar i första hand till den nya svenska adoptionsforskning som undersöker vuxna utlandsadopterades situation utifrån olika befolkningsregister snarare än till den traditionella adoptionsforskningen. Denna nya forskning har påvisat att många adopterade som vuxna mår och klarar sig sämre än både majoritetsbefolkningen och den icke-adopterade invandrarbefolkningen i landet. Detta gäller bland annat psykosocial problematik i form av psykiska sjukdomar, olika former av missbruk, kriminalitet och suicidförsök (von Borczyskowski et al. 2006, Hjern \& Allebeck 2002, Hjern et al. 2002). Faktum är att ingen annan grupp i Sverige är så drabbad av genomförda självmord som just utlandsadopterade med en fyrfaldig överrepresentation jämfört med motsvarande svenskfödda grupper med samma sociala bakgrund.

Den nya svenska adoptionsforskningen har också uppmärksammat att vuxna adopterade inte uppnår samma socioekonomiska nivå som grupper med jämförbara uppväxtvillkor. Detta gäller bland annat eftergymnasial utbildningsnivå, etablering på arbetsmarknaden, sjukskrivning, förtidspensionering och långtidsbidragstagande, trots att de utlandsadopterade överlag har växt upp med högutbildade och välbärgade föräldrar (Carlberg \& Nordin Jareno 2007, Lindblad et al. 2003, Rooth 2001, 2002, Österberg 2000). För att sammanfatta: i jämförelse med icke-adopterade migranter uppvisar utlandsadopterade en svårare psykosocial 
problematik, samtidigt som de båda grupperna riskerar att som vuxna deklasseras till en lägre socioekonomisk nivå jämfört med den infödda majoritetsbefolkningen. Dessa resultat har förklarats med en kombination av negativa psykologiska upplevelser före adoptionen och, framför allt, genetiskt arv. Vi antar emellertid att de nedslående resultaten istället kan förstås och förklaras som effekter av diskriminering på grund av ett icke-vitt utseende.

Den svenska IMER-forskningen har sällan eller aldrig inkluderat adopterade som forskningsobjekt på grund av att adoption har separerats från den internationella migrationen, och att de adopterade därigenom inte betraktas som migranter. Eftersom IMER-forskningen i allmänhet fokuserar på migrant- och minoritetsgrupper som uppfattas som etniskt annorlunda och socialt utsatta och traditionellt inte beaktar utseendemässig olikhet, så har svensk forskning om adopterade respektive invandrade fram tills nu varit helt åtskild. Vi anknyter därför i första hand till den nya svenska diskrimineringsforskningen, snarare än till den klassiska IMER-forskningen.

Vi vill här särskilt lyfta fram ett antal intervjubaserade diskrimineringsstudier som undersöker särbehandling av migranter i vardagen och där även adopterade ibland ingått som informanter (Hällgren 2005, Kalonaityté et al. 2007, Kamali 2005, Lundström 2007, Motsieloa 2003, de los Reyes et al. 2002, Sawyer 2000, Schmauch 2006). Sawyer (2000) har intervjuat 20 svenskar med ett svart utseende representerandes både de så kallade första och andra generationens invandrare liksom enstaka adopterade, och hon visar hur denna disparata grupp som räknar ursprung från en mängd olika länder och regioner tenderar att identifieras med en kollektiv svarthet. Motsieloa (2003) har också inkluderat både invandrade och adopterade i sin intervjustudie rörande upplevelser av vardagsrasism bland icke-vita ungdomar i Sverige, och detsamma gäller även Kalonaitytes et al. (2007) intervjustudie om erfarenheter av diskriminering bland ungdomar med svart afrikansk bakgrund. Båda dessa rapporter visar att processer av rasifiering ständigt pågår i den svenska vardagen, vilka därmed reproducerar föreställningar om raser trots den officiella svenska frånvaron av ras och trots att rasism normalt enbart kopplas till explicita rasideologiska och nationalsocialistiska sammanhang, vilket leder till att många informanter har svårt att själva benämna sina upplevelser som rasism. Lundström (2007) bygger sin studie på intervjuer med 29 gymnasieelever med latinamerikansk bakgrund varav några är adopterade, och intresserar sig för sambandet mellan diskriminering och etnisk identifikation i en latinamerikansk diasporakontext. Särskilt med utgångspunkt i de adopterades alienationskänslor inför sina icke-vita kroppar, visar Lundström hur utseendebaserad svenskheten är genom att den hela tiden kopplas samman med att ha ett vitt utseende.

Föreliggande studie kan ses som vårt bidrag till försöken att överbrygga och föra samman den nya svenska adoptionsforskningen med den nya svenska diskrimineringsforskningen, liksom att fylla bristen på adoptionsstudier där kulturens och samhällets roll betonas framför individens och familjens, och där det psykologiska och medicinska perspektivet får stå tillbaka för

Tobias Hübinette \& Carina Tigervall: Erfarenheter av rasifiering hos adopterade... 
det samhällsvetenskapliga och det kulturteoretiska.

\section{Underlag, frågeställningar och begreppsram}

Detta är en kvalitativ studie där inspelade och transkriberade samtal med 20 vuxna adopterade och åtta adoptivföräldrar, vilka genomfördes under första hälften av 2007, utgör det empiriska underlaget. Intervjuerna var semistrukturerade och ägde rum vid ett tillfälle och varade mellan 1-2 timmar. De adopterade informanterna fick i efterhand läsa utskrifterna och gavs då möjlighet att korrigera eller redigera dessa, och flera deltagare inkom även i efterhand med egna skriftliga tillägg och klargöranden. Centrala teman som fördes in i samtalen med de adopterade var upplevelser av diskriminering i det svenska samhället; upplevelser av att ha blivit särbehandlade i skolan och arbetslivet; åsikter om stereotypa bilder av den egna gruppen; känslor av att höra till respektive inte höra till majoritetsbefolkningen; och tankar kring gruppidentifikation respektive individuell personlighet. Teman som fördes in i samtalen med adoptivföräldrarna var oro för och erfarenheter av särbehandling, diskriminering gentemot barnen och familjen; erfarenheter av fördomar inom den egna släkt- och vänskapskretsen; erfarenheter av möten med andra adoptivfamiljer och vuxna adopterade; och strategier för att hantera upplevelser av att bli bemött som annorlunda. I denna artikel är det dock främst resultat med avseende på en av dessa aspekter som redovisas, nämligen adopterades och adop- tivföräldrars erfarenheter av diskriminering.

Vi utgår ifrån ett socialkonstruktivistiskt perspektiv med inspiration från postkoloniala feministiska studier och amerikansk kritisk ras- och vithetsforskning, vilket innebär att vi ser kategorier som etnicitet och ras som historiskt och politiskt inbäddade, och socialt och kulturellt konstruerade. Denna teoretiska utgångspunkt innebär att exempelvis kategorin svenskhet redan från början betraktas som skapad inom ett specifikt historiskt och politiskt sammanhang, och aldrig har existerat som något autentiskt eller ursprungligt. Begreppet etnicitet brukar beskriva tillhörighet till en viss folkgrupp med avseende på kultur, religion, språk, nationalitet och ibland också utseendemässiga karaktäristika (Hylland Eriksen 1993, Lange \& Westin 1981, Olsson 1999, Westin 1999). Centralt är att begreppet är relationellt och kopplat till makt, liksom att det ständigt är under förhandling och i förändring. Etnisk identitet får betydelse när människor väljer att ge den betydelse, såsom i samband med exkludering från majoritetssamhället. I fallet adopterade och adoptivfamiljer handlar dock den netniska" aspekten uteslutande om utseendemässiga särdrag, förknippade med ett visst geografiskt och genetiskt ursprung. Att hävda att adopterade har en annan etnicitet än en svensk etnicitet är därför orimligt då människor som växer upp i etniskt-kulturellt svenska familjer bör betraktas som etniska svenskar.

En av studiens avsikter är att problematisera etnicitetsbegreppet med utgångspunkt i begreppet rasifiering. Termen rasifiering 
(racialization) härrör från anglosaxisk kritisk rasforskning, och syftar på den praktik och process som tillskriver individer och grupper olika egenskaper och beteenden utifrån utseendemässiga särdrag, och som kategoriserar och hierarkiserar raser utifrån historiskt förankrade föreställningar (Anthias \& Yuval-Davis 1992, Miles 1989, Molina 2005, Omi \& Winant 1994). Inom den postkoloniala teoribildningen anses dessa föreställningar om raser härstamma från den västerländska modernitetens och kolonialismens vetenskapliga kunskapsproduktion vilken framför allt ägde rum under 1800- och 1900-talen. Vår användning av rasifieringsbegreppet syftar i första hand på vardagliga händelser av särbehandling, det vill säga upplevelser av att behandlas annorlunda och bli exkluderad och marginaliserad utifrån utseendemässig olikhet $\mathrm{i}$ vardagslivet, vilket brukar benämnas som vardagsrasism eller vardagsdiskriminering (Essed 1991, Mattsson \& Tesfahuney 2002, de los Reyes \& Wingborg 2002).

Rasifiering är det centrala begreppet för vår studie, eftersom vi menar att insorterandet $i$ och hierarkiserandet mellan raser även drabbar icke-vita adopterade på samma sätt som det drabbar andra med icke-normativa kroppar. Som vi kommer att se utifrån vårt material, så är det dock mycket svårt för att inte säga omöjligt att skilja mellan begreppsparen etnicitet och ras och därmed också de praktiker som ger upphov till kategorierna, det vill säga etnifiering och rasifiering, då sådana etniska tillskrivningar som språk, kultur, religion, ursprung och hemvist hela tiden faller tillbaka på en viss kropp som avläses som en viss ras, sammankopplad med en viss etnicitet. ${ }^{3}$ Det är vidare inte den icke-vita kroppen i sig som vi menar orsakar att icke-vita människor uppmärksammas som och behandlas annorlunda, utan just den rasifieringsprocess som hela tiden pågår när människor interagerar med varandra i vardagen. Vår huvudsakliga teoretiska utgångspunkt för studien är således att det inte är existensen av raser som orsakar rasifiering utan tvärtom: det är rasifieringsprocesser som har skapat och som än idag reproducerar föreställningen om raser. Liksom etnicitet är ras inte något som människor är eller har i sig, utan något som människor tillskrivs och tillskriver andra och sig själva genom att sortera in individer och grupper utifrån olika utseendetyper. Vi tar därmed kraftfullt avstånd från rasbegreppet $\mathrm{i}$ dess traditionella essentialistiska bemärkelse, det vill säga som ett biologiskt, statiskt och oföränderligt tillstånd. När vi i följande redovisning använder rasbegreppet, gör vi därför detta med en medvetenhet om begreppets problematiska historia, och som en följd av att vår empiri vittnar om att ett icke-vitt utseende verkligen har betydelse i adopterades och adoptivfamiljers vardagsliv.

I den följande resultatredovisningen visas genom ett urval av extrakt från intervjuerna hur ett icke-vitt utseende relateras till olika kontextbundna situationer, platser och rum. Offentliga rum där allt från hypervisuell synlighet $\mathrm{i}$ "helsvenska» vita

3 På ett liknande sätt fungerar även begreppsparen genus och kön, det vill säga att vissa egenskaper som uppfattas som kvinnliga eller manliga faller tillbaka på en viss kropp som avläses som ett visst kön.

Tobias Hübinette \& Carina Tigervall: Erfarenheter av rasifiering hos adopterade... 
övre medelklassmiljöer till "tullrasism" och "lekplatsrasism" inkluderas, liksom privatsammanhang och intimsfärer där särbehandling och diskriminering från släktingars och närståendes sida ingår, samt även hur skiftet mellan kända och okända geografiska platser, såsom vid flyttning från uppväxtort till storstad, påverkar och aktiverar olika erfarenheter av rasifiering.

\section{Rasifiering i det offentliga rummet}

Den särbehandling som de adopterade utsätts för i vardagslivet i det offentliga rummet skiljer sig inte i någon högre grad från den som invandrare erfar, vilken dokumenterats $i$ ett flertal tidigare studier. Åtskillnaden mellan dessa båda grupper, som så radikalt skiljer sig åt från varandra etniskt-kulturellt och socioekonomiskt, har en tendens att kollapsa i den svenska majoritetsbefolkningens ögon på grund av en gemensam nämnare: deras icke-vita utseenden. Det är därför inte förvånande att vanliga exempel på diskriminering $i$ butiksmiljö, i krogkön samt i tullen, också återges av de adopterade informanterna.

Isabella: Jag och en kompis som är adopterad från Colombia var $i$ en affär och blev förföljda av ägaren - det var ganska obehagligt. Och när jag och samma kompis plus en kompis med helsvenskt ursprung hade varit i Köpenhamn blev min colombianska kompis stoppadi tullen, men jag och den andra kompisen kunde gå igenom utan problem. Det var på den tiden när man åkte färja, men vi har även fätt bilen stoppad på bron, men jag behövde inte visa körkort eftersom jag pratade så bra svenska.

Isabella som är adopterad från Bangladesh vittnar både om extra övervakning i affärer, och om problemet med att komma tillbaks till Sverige från en utlandsresa och behöva visa pass samt prata flytande svenska för att bevisa sin nationella tillhörighet och hemhörighet. Det verkar också som att tulltjänstemännen och gränspoliserna särbehandlar olika typer av icke-vita kroppar, att döma av att Isabellas väninna som är adopterad från Colombia ibland stoppas utan att Isabella tas in för genomsökning, förmodligen utifrån föreställningen om latinamerikaner som kriminella. Isabella kontrasterar dessa upplevelser med sina resor till USA och Storbritannien, och där hon inte har haft några problem med att passera tullen, och hon nämner detta för att illustrera hur svenskheten så starkt kopplas samman med anatomisk-visuell vithet. ${ }^{4}$

Fredrik: Jag var en gång med en dåvarande flickvän och kompisar till henne, och vi stod i en bankomatkö. Då var där några svenska killar som var äldre än mig, och direkt sà började de säga jävla neger och så vidare, och de sade det inte subtilt utan halvhögt. Då blir man väldigt utsatt, för jag var med min dåvarande flickvän och hennes kompisar, och jag var ju ganska ensam där.

4 "Tullrasismen« och s.k. »racial profiling" är ett välkänt internationellt fenomen inom både forskningen och politiken, och inom EU uppmärksammas problemet regelbundet av bl.a. ECRI (European Commission against Racism and Intolerance) och Open Society Justice Initiative (Côté-Boucher 2008). 
Fredrik som är adopterad från Dominikanska republiken berättar om hur han plötsligt och oväntat i sällskap med vita bekanta kan förnedras offentligt i sådana vardagliga situationer som när han ska ta ut pengar. Fredrik uttrycker en frustration över att vara helt ensam som icke-vit i sådana sammanhang utan att vara säker på om han får stöd och "uppbackning» av sina vita vänner, och utan att vara säker på om de ens registrerade kränkningen eller ej. Fredrik hävdar att denna typ av vardagsrasistiska händelser äger rum just när han är i sällskap med vita personer som står honom nära, som om det provocerar extra mycket när icke-vita står nära vita människor. Det går också att anta att denna typ av rasifierande trakasserier upplevs som än mer skamfylld och förnedrande just när den äger rum i närvaro av vita svenskar som står de adopterade nära såsom deras föräldrar, partners och vänner.

Andreas: Jag har varit med om mycket, men jag vet inte om det är rasism, jag vet inte. Som på morgonbussen, och då har jag bara bott i områden där det bor svenskar, jag har inte alls bott $i$ invandrartäta områden. Så åker man med bussen, men ingen sätter sig bredviden, de står hellre upp! Och då undrar man, jaha, för jag luktar inte illa, jag ser inte jätteful ut, jamen du vet! Eller som när man går hem från krogen och det går någon framför en, och de blir rädda. Jaha, de är rädda för att jag är svart, det visar de väldigt väl. Och gamla tanter som stoppar in väskan, för det finns väldigt mycket att man är kriminell, att man är en invandrare som ska råna dem. Och går du in på ICA så följer de efter dig, en sådan där vakt, eller att de inte tar fram guldet när jag är i en guldaffär.
Erfarenheter av rasifiering i det offentliga rummet handlar för de adopterade som bor och lever i urban miljö ofta om situationer "på gatan" där för dem okända vita svenskar markerar ogillande distans eller fientlighet genom att placera sig och röra sig utifrån ett koreograferat kroppsspråk som kommunicerar skillnadsskapande och avståndstagande. Att svarthet särskilt starkt associeras med våld känns väl igen från en amerikansk kontext, och att så också är fallet i Sverige kan förklaras med att denna typ av rasifierande diskurs importerats från USA och förstärks och upprätthålls genom den allestädes närvarande amerikanska populärkulturen.

Ett vardagligt sammanhang utanför hemmet som flera adoptivföräldrar berättar om, är hur deras barn utsätts för negativa kommentarer och utestängande behandling från okända på lekplatser. Mia myntade begreppet "lekplatsrasism", vilket har en mycket otäck laddning med tanke på att rasism och lekplats är två begrepp som borde stå så långt ifrån varandra som möjligt, men som alltså inte alltid gör det.

Mia: Och sen så det man märker är ju den här lekplatsrasismen som finns. När man har varit på någon allmän lekplats, och man häller sig $i$ bakgrunden, och de sitter och leker, framförallt Oscar då som är väldigt mörk, på något sätt har det varit tydligast med honom som är mörkast, man kan höra 'jag vill inte sitta i sandlådan med den här bruna pojken', jag menar hade någon sagt 'jag vill inte sitta $i$ sandladan med den blonda flickan med den rosa kjolen', då hade man sagt att 'alla måste få vara $i$ sandlàdan', då hade man varit framme och förma-

Tobias Hübinette \& Carina Tigervall: Erfarenheter av rasifiering hos adopterade... 
nat, men i det här fallet har man inte gått in från vuxet håll och gjort någonting/.../Sedan har jag märkt att om jag börjar närma mig, att de börjar koppla ihop, så de ser att han hör ihop med mig, då börjar de bete sig mer normalt. Då blir det mer att man säger till att 'alla måste vara med, alla måste få vara här'. Och det är en intressant iakttagelse: 'oj då, han är tydligen inte bara vilken invandrare som helst'.

Här beskrivs hur »bruna barn" särbehandlas genom att utestängas av andra barn i leksituationen, i det här fallet från att vara med i sandlådan. Det mest anmärkningsvärda här är dock att de föräldrar som annars förväntas uppmuntra demokrati och likabehandling här tycks ignorera sitt eget vita barns utestängande hållning gentemot ickevita barn. Uppenbart är också att när det icke-vita barnet kan identifieras som ett adoptivbarn, och därmed som ett legitimt svenskt barn, börjar dessa föräldrar »bete sig normalt» vilket innebär att de demokratiska principerna om allas lika rätt till sandlådan återupptas. Detta kan ses som en illustration från sandlådeperspektiv av hur ett diskriminerande samhälle fungerar: endast vissa, vita, barn/människor betraktas som att ha rätt till sandlådan/Sverige. Bruna barn/människor kan utestängas genom svenska barns/myndigheters bevakning av sandlådan/nationsgränserna. När ett icke-vitt barn/en icke-vit person kan identifieras som legitimt svensk genom förälderns vithet alternativt juridiska dokument som bevisar rätten att beträda sandlådan/Sverige upphör gränsbevakningen och lika rättigheter kan börja gälla.

Negativa upplevelser av att bli upp- märksammad som annorlunda och betraktad som icke-tillhörande förstärks genom konkreta erfarenheter av att ifrågasättas i samhälleliga institutioner, exempelvis i samband med att man passerar tullen (vid Sveriges, inte bara sandlådans gräns), vilket också är en starkt symbolisk institution i den bemärkelsen att det är där tillhörande respektive icke-tillhörande identifieras, och där vissas legitimitet därmed står i kontrast mot andras illegitimitet. Främst tänker man kanske på flyktingar vars tillträde till många västländer är mycket hårt begränsat, men även turisters visumtvång och andra situationer kopplade till nation och juridik. I intervjuerna med adopterade och adoptivföräldrar nämns också tullen som ett typexempel på hur adopterade uppmärksammas som inte självklart legitima svenskar: det fysiskt-kroppsliga utseendet ses där som mer signifikant än det nationella medborgarskapet.

Att olika former av rasifieringsprocesser utspelar sig i den svenska vardagen visar vår studies empiri tydligt. I de ovanstående extrakten har vi främst redovisat erfarenheter av otvetydigt negativt slag. Den vanligaste formen av annorlundisering som kommenteras av de intervjuade är dock frågebombardemanget om de adopterades ursprung som såväl de själva som adoptivföräldrarna upplever som återkommande inslag i vardagen. Vissa av informanterna ser dessa frågor som "nyfikna» och "trevliga", medan andra uppfattar dem som den vanligaste och mest subtila formen av exkludering ifrån och ifrågasättande av tillhörighet till den svenskhet som de adopterade i första hand identifierar sig med. Många adopterade tvivlar dock på sina 
egna upplevelser av rasifiering, och även antirasistiskt medvetna adoptivföräldrar kan ibland ha svårt att tala om diskriminering baserat på utseende, utan gör det ofta till en fråga om mobbning, handikapp eller ursprung, alternativt till en fråga om avsaknad av blodsband. Vi tolkar denna attityd som ett uttryck för ett tabu att tala om etniskt-rasliga skillnader och icke-vita kroppar till följd av Sveriges officiella självbild som ett icke-rasistisk land.

\section{Geografiska och demografiska platsers betydelse}

Olika platsers socioekonomiska och etnisktkulturella demografiska sammansättning har betydelse för, om och hur rasifiering upplevs. Skillnaderna mellan upplevelser av särbehandling i homogena småstäder kontra mer utseendemässigt blandade mellanstora och storstäder är stora med avseende på att exempelvis bli utstirrad. Den homogena småstaden omnämns ofta som en problematisk plats för icke-infödda eller på annat sätt fysiskt-kroppsligt icke-normativa människor, men inte heller storstaden upplevs som ett tolerant socialt rum, då segregationen och antagonismen mellan infödda och inflyttade kan vara större där än i mindre och mellanstora städer. De adopterades olika livshistorier och de därmed sammanhängande referensramar och erfarenhetsbanker som dessa ackumulerat på olika orter illustrerar väl olika platsers betydelse.

Sofia: Det var verkligen här $i$ Stockholm efter att jag flyttade hit som jag stötte på de första rasistiska påhoppen som jag kan komma ihåg. Kanske var det någon gång innan, men det var få gånger. Här hände det ju plötsligt ofta tyckte man, eller en gång $i$ månaden $i$ alla fall. Det hade jag ju aldrig upplevt, så det var en chock att plötsligt bli utsatt för den sortens hat.

Sofia som är adopterad från Korea växte upp på en liten ort i Småland där alla visste vem hon var, det vill säga att hon var adopterad och inte invandrad, och det var därför först när hon flyttade till Stockholm som hon upplevde en mer tydlig aggressiv rasifiering i det offentliga rummet. Sofia nämner särskilt barn och äldre, och dessa är också de grupper som utpekas som de vanligaste utövarna och förövarna av verbal rasism i en intervjustudie som undersöker erfarenheter av sexualisering i offentligheten bland vuxna adopterade kvinnor födda i Öst- och Sydostasien (Signell \& Lindblad 2006/07). Där framgår att vita barn och vita pensionärer för många till och med kan framkalla skräck och ångest genom sin blotta fysiska närvaro på grund av att de adopterade aldrig kan vara helt säkra på vilka verbala attacker som när som helst kan komma från dessa.

Rebecka: Ett tag bodde jag i Stockholms innerstad, och där kände jag verkligen, här passar inte jag in! Det fanns inga mörkhyade personer, och jag upplevde, fast det var säkert min osäkerhet, att folk tittade snett på en, så därifrån flyttade jag ganska snabbt till en förort där jag definitivt kände mig mer hemma.

Samtliga utom två av de adopterade infor-

Tobias Hübinette \& Carina Tigervall: Erfarenheter av rasifiering hos adopterade... 
manterna bodde vid samtalens genomförande i svenskdominerade medelklassområden. Rebecka har dock idag valt att bosätta sig i ett blandat bostadsområde efter att ha prövat på Stockholms svenskdominerade och socioekonomiskt resursstarka innerstad respektive en invandrartät proletär förort, och hon påstår att hon trivdes bäst i det sistnämnda området där hon utseendemässigt kände sig mer bekväm och bättre bemött.

De adoptivföräldrar som intervjuats reflekterar över valet av bostadsort på ett liknande sätt. Främst framhåller dessa dock att nätverk och socioekonomisk likhet är viktigare för familjen än etnisktraslig likhet. Men även utseendeaspekten har föresvävat flera av dem, och några har också, som en konsekvens av detta, strategiskt valt att bosätta sig på platser där ett vitt utseende inte är helt dominerande. Åsa och hennes familj valde att bosätta sig på en ort där hud- och hårfärger är högst varierande, genom att en hög andel invandrarfamiljer är bosatta där, varför ett adopterat barn med mörk hudfärg inte skiljer åt från mängden. ${ }^{5}$

Åsa: När barnen började på dagis, var vi rätt tacksamma att vi fick ett dagis där det var många olika hudfärger, jag tyckte det var bra, just för att man inte skulle sticka ut i gänget utan acceptera att alla kan se olika

5 Flera studier har dessutom indikerat att strukturell diskriminering på bostadsmarknaden är en viktig orsak till den låga andelen av självvald bosättning i s.k. "invandrartäta» förorter (Andersson \& Molina 2003, Bråmå 2006, Molina 1997). ut, och det var ett jättebra dagis. Men jag är inte helt övertygad om att det var jättelyckat ändå. Därför att de barnen, de visste sin-det var så grymt - de visste sin plats så tidigt. SåNoah då, den minsta killen, han är lite mörkare i sin färg...då mätte barnen sin hudfärg och den som var ljusast, hade högst status. Och det där tog jag upp med dagisledningen och de hade inte uppmärksammat det här och blev ju jättebekymrade och man pratade mycket om det, så jag tyckte de behandlade det korrekt, men det visar ju att de här [invandrar] barnen som kom till Sverige, de upplevde ju redan då att det var en skillnad och den vidareförmedlade de då till våra [adopterade] barn.

Här ser vi hur Åsas val att bo på en etnisktraslig heterogen plats ändå resulterade $\mathrm{i}$ att barnet råkade ut för en tydligt rasifierande praktik i barngruppen, där status räknades efter grad av mörkhet. Detta kan tyckas som ett grymt tilltag av de invandrarbarn som iscensatte detta, men det är egentligen bara en spegelbild av hur samhället är strukturerat, såväl globalt som lokalt. Uppenbart är att vissa invandrarbarn har en stor medvetenhet om rashierarkier som de på detta brutala sätt kan delge adopterade, vilka annars har förmånen att leva i de mest socioekonomiskt välbeställda familjerna, och inte på samma självklara sätt direkt upplever de globala, nationella och lokala hierarkierna och orättvisorna.

\section{Rasifiering i skolan}

När det gäller olika former av diskriminerande uttalanden och händelser är detta 
inget adopterade skolbarn går fria från $\mathrm{i}$ skolmiljön, trots att detta är en plats där människors lika värde är en av de officiella hörnstenarna. Oftast handlar det om uttalanden från andra barn.

Mia: När Oscar gick här hos dagmammorna, han var inte gammal jag tror han var fyra år, och de lekte affär, och då var det någon som bestämde att han fick inte handla $i$ affären för han var brun. Och det var inom den här barngruppen. Och sedan påpekade vi det för dagmammorna och de blev jättechockade och 'så ska det inte vara'. Det finns en naiv föreställning om att så små barn tänker inte ens $i$ de här banorna och så blir vuxenvärlden jättechockerade att det händer. Jag menar små barn brukar ju avspegla resten av samhället, så jag tycker inte det är konstigt att det händer. Däremot tycker jag det är konstigt att man är så omedveten. Och att det känns som, det är också en sån här brist man kan känna att förskolepersonal och skolpersonal inte har så mycket kunskap och inte har funderat igenom sina egna fördomar och föreställningar heller.

Mia: Det här att Oscar är brun som en bajskorv, den typen av kommentarer. I skolan...

Carina: vad har hänt då?

Mia: det händer inte så mycket, det är det som, det man kan känna är ju att barnen är ju smarta, för de vuxna är ju på sina vuxenfält, särskilt $i$ skolan, då är det som att man har rastvakter. Rastvakterna står ju på sina givna platser, det vill säga att precis framför rastvakterna händer ju ingenting, men sedan vet man att går man 50 meter åt någon annan riktning, där händer det rätt så mycket... där förekommer ju att 'du fär inte komma på mitt kalas', och att 'du är brun', men man gör det aldrig framför vuxna för man vet att de kommer ju att säga ifrån.

Mias berättelser om hennes barns upplevelser i skolan visar på problemet med rasifiering i det svenska samhället: bakom en demokratisk fasad, här exemplifierat med den mest centrala samhällsinstitutionen - skolan, förekommer kränkande kommentarer ("brun som en bajskorv ") och utestängande handlingar ("du fär inte handla $i$ affären", "du får inte komma på mitt kalas") riktade mot icke-vita barn. Idén om människors lika värde och den negativa särbehandlingen finns på samma plats, men särbehandlingen sker utom hörhåll för de som finns där för att förhindra kränkningar. Mias berättelse ger en mångdimensionell bild av hur icke-kompatibla värderingar existerar sida vid sida, och hur komplicerat det är att som kritiker intervenera i detta.

Att under uppväxten behandlas annorlunda i skolan och bli utpekad på grund av ett icke-vitt utseende är en erfarenhet som samtliga adopterade deltagare också kan relatera till, och som också känns väl igen från tidigare studier av erfarenheter av särbehandling i skolmiljö bland ungdomar med migrantbakgrund (Runfors 2003, Sawyer 2000, Schmauch 2006). I samtalen framkom det att inte bara andra barn uppmärksammade deras kroppsliga annanhet under skolåren, utan även att vuxna i form av lärare och annan skolpersonal särbehandlade dem på olika sätt, vilket är än mer anmärkningsvärt just eftersom det äger

Tobias Hübinette \& Carina Tigervall: Erfarenheter av rasifiering hos adopterade... 
rum inom ramen för en uttalat demokratisk institution. En återkommande berättelse handlar om hur informanterna kopplades samman med andra klasskamrater med utländsk bakgrund, och detta oavsett ursprungsland.

Alexander: Den första egentliga kontakten jag fick med en annan kultur var $i$ 4: an när det kom en pojke från Kurdistan. Jag var ju den ende mörka $i$ klassen, så jag fick så klart bli hans kompis och skulle ta hand om honom.

Tobias: Men vem bestämde det?

Alexander: Fröken.

Alexander, som är adopterad från Sri Lanka, sattes av sin klassföreståndare att "ta hand om" en kurdisk invandrarpojke trots att de knappt kunde kommunicera med varandra. Arvid som är adopterad från Chile sattes likaledes att "ta hand om" två kinesiska invandrarbarn som kom till hans klass i 3:an. Detta från vuxenvärldens sida aktiva sammanförande av adopterade med invandrade, visar hur icke-vita kroppar tenderar att smälta samman till en enhetlig icke-vit gruppering. Även flera av de intervjuade adoptivföräldrarna berättar om liknande episoder.

Mia: I ettan var det en kille som började, han kommer från Senegal, när de är ute och går, så parar de ihop barnen två och två, så ska de liksom gå på led, och av någon anledning så var det allid Hassan och Oscar som gick tillsammans, och det var ju inget problem $i$ sig, men till slut sa Oscar så här: 'varför ska jag alltid gå med Hassan, jag vill gå med Carl'! Och det kändes som att, jag tror det var helt omedvetet, att man parade ihop de här två mörka killarna.

När det gäller att para ihop barn på grundval av utseende kan man anta att detta, även om det sker omedvetet, handlar om man vill värna barn som kan antas känna sig annorlunda i relation till majoritetsgruppen, och att då icke-vita barn förs samman till en kategori som antas ha ett gemensamt intresse vid sidan av majoritetsgruppen. I praktiken är det dock en segregerande och separatistisk praktik att särskilja grupper på grundval av rasligt utseende, som på andra håll i världen kallats apartheid, och vilket är en rasistisk historisk praktik som skolan har till uppgift att ta starkt avstånd ifrån och att dessutom undervisa barnen om. Att då skolans personal använder sig av denna praktik har en mycket stark symbolisk betydelse, även om det för de enskilda barnen inte alltid behöver vara negativt att paras samman med andra vars utseende liknar deras eget.

\section{Rasifiering i intimsfären}

I intervjuerna med adoptivföräldrarna framkom flera exempel på hur, främst äldre, släktingars negativa attityder till icke-vita människor är en del av adoptivfamiljens specifika situation som en etniskt-rasligt blandad familj.

Åsa: Noa är ju mörk, han blir ju då lätt väldigt solbränd, och kan då se, $i$ ett svenskt perspektiv kan han se lite smutsig ut, och det vet jag att min mamma reagerat mot och det har jag sagt till henne, på skarpen har jag 
sagt till faktiskt, att det tolererar inte jag, utan hon fär ta dem precis som de är, och passar det inte så.

Carina: Det här din mamma sa, det är sådant hon sagt till dig när barnen inte hört på?

Åsa: Jaa, ja, så är det nog, och där har jag ett jätteproblem, och det har jag sagt till henne, eeh, för henne finns det 'svenskar' och 'utlänningar' och det här språkbruket, hon bor $i$ X-stad och så har hon en liten butik utanför som då ägs av, i hennes perspektiv, av en 'utlänning', och 'du kan gå till utlänningen och köpa...'. Och jag har sagt att 'jag tycker inte att, det är ju en individ, varför ska du behöva'. Och det här språkbruket det förekommer jupåandra häll.

När det gäller att bemöta och hantera denna typ av uppfattningar uppstår ofta problem relaterade till möjligheten att ha ett fortsatt gott umgänge med människor i bekantskapskretsen. Som adoptivförälder har man genom sitt val att adoptera internationellt ofta tagit ställning mot rasism, men det innebär inte att andra i släkten delar denna övertygelse. När det gäller ens närmaste släktingar kan det också vara ett än större dilemma, eftersom en konfliktsituation kan uppstå om man protesterar mot släktingars rasifierande språkbruk som kan få stora konsekvenser för såväl adoptivföräldrarna som barnen: antingen undviker man kontakt, och medverkar till att barnet inte får kontakt med vissa nära släktingar, eller så riskerar man att utsätta sitt barn för rasistiska uppfattningar som man vill att de ska slippa.

Även för de adopterade äger upplevelser av rasifiering inte bara rum i det offentliga rummet, utan flera av informanterna berättar också om erfarenheter av att ständigt bli utpekad och särbehandlad även inom intimsfären, det vill säga bland familjemedlemmar och nära vänner.

Linnea: Jag har alltid blivit utpekad $i$ hemmiljön. Så fort det har varit något om Korea på teve så har de sagt, titta det är om Korea! Och om det kommer fram något om Korea, så har de alltid emfaserat det gentemot mig som om jag inte hade uppfattat det första gången. Och mamma har sina favorithistorier, som till exempel när jag kom till Sverige och sitter och tittar ned i golvet. Hennes favorithistoria som hon har berättat hundra gånger tror jag, det är att min kusin säger, titta det ser ut som om hon sover, för att jag har så smala ögon. Det har roat henne hur många gånger som helst!

Linnea vittnar om hur hennes annorlunda utseende hela tiden har påpekats och lyfts upp inom familjen och släkten ända sedan hon kom till Sverige från Korea. Linnea växte upp i ett övre medelklassområde $\mathrm{i}$ en Stockholmskommun, och framför allt hennes adoptivmor har en hel uppsättning skillnadsskapande anekdoter och berättelser att förtjust förmedla till väninnor och bekanta rörande Linneas fysiskt-kroppsliga annorlundahet. I egenskap av adoptivförälder till ett asiatiskt barn, tittar Linneas adoptivmor också gärna lite extra på andra asiater i det offentliga rummet, och hon påstår ofta att hon ser asiater "på stan" som liknar sin dotter utifrån den välkända logiken att alla icke-vita, och kanske särskilt öst- och sydostasiater, med en västerländsk blick framstår som utseendemässigt

Tobias Hübinette \& Carina Tigervall: Erfarenheter av rasifiering hos adopterade... 
klonade kopior. Linnea har inte protesterat mot denna typ av utpekanden av hennes annorlunda utseende i intimsfären, men samtidigt håller hon inte med om att hon liknar speciellt många andra asiater hon har stött på i Sverige, och det är tydligt att hon inte har mått speciellt bra av att hela tiden få höra att hon ser annorlunda ut från de som står henne närmast.

\section{Icke-vita svenskar - ras/etnicitet och rasifiering/ etnifiering}

En föreställning som gör sig gällande än idag är en upplevd och föreställd korrelation mellan språk, namn och utseende. Vita människor förväntas tala västerländska (indoeuropeiska) språk som modersmål, och likaså förväntas vita människor tilldelas och bära västerländska (kristna) namn.

Simon: Jag upplever att det mest är barn och gamla som säger saker som gör mig ledsen. Att, oj kan du svenska, och att jag möts med skepsis. Jag har gjort praktik $i$ sådana där små hålor, och då har det känts att de är jätteskeptiska först, men sedan tycker de, jaha men den här personen kan svenska och har ett svenskt namn! Så innan jag öppnar munnen och pratar så tänker de att jag är invandrare, men sedan när jag gör det, då omvärderar de. Det är ju jättejobbigt i varje möte, att man måste förklara sig.

Simon som är adopterad från Korea uttrycker en stor frustration över att detta samband mellan språk och namn och etni- citet och ras ständigt aktiveras i vardagssituationer, förutom att han återknyter till det faktum att särkilt barn och gamla verkar vara de som oftast ifrågasätter hans tillhörighet till och identifikation med Sverige. Simon har genom sitt yrke praktiserat på mindre orter runtom $i$ landet, och menar att varje gång han träffar nya vita svenskar så måste han förklara och närmast ursäkta dissonansen mellan varför han ser ut som han gör, och varför han talar flytande svenska och bär ett kristet namn.

Språket är förmodligen det som uppfattas som den yttersta markören för nationell tillhörighet. Att vita adoptivföräldrar med icke-vita barn får kommentarer kring barnens språkliga kompetens vittnar flera av de intervjuade om:

Mia: Det är många som frågar om vi pratar engelska med barnen, som frågar vad vi pratar för språk med dem, så de ska förstå vadvi säger.

Carina: Vilka frågar om det?

Mia: Vuxna människor! Välutbildade som borde kunna tänka, men som då frågar vad vi pratar för språk med dem. Då brukar jag säga att jag pratar svenska för jag är så dålig på Bengali.

\section{Konklusion}

Vårt material visar hur de adopterades icke-vita kroppar regelbundet och systematiskt lokaliseras till ett visst geografiskt ursprung, förankras i en viss nationalitet, och tillskrivs olika etniska egenskaper trots att de adopterade är etniskt-kulturellt svenska. Trots denna kompakta förankring 
i svenskheten i form av ett svenskt medborgarskap, svenska som modersmål, en kristen och västerländsk namnuppsättning och framför allt ett svenskt släktskapssammanhang, så rasifieras de adopterade i vardagen, samtidigt som de också etnifieras. Med detta vill vi, som vi påpekade i inledningen, än en gång argumentera för att ras och etnicitet är lika oskiljaktiga som kön och genus, det vill säga att samtidigt som de adopterades icke-vita kroppar rasifieras, det vill säga identifieras och kategoriseras som en viss rastyp, så etnifieras de genom att tillskrivas en mängd andra etniska egenskaper än svenska sådana. ${ }^{6}$ Det är inte heller alltid lätt att skilja mellan dessa två praktiker, då åtskillnaden mellan ras och etnicitet hela tiden tenderar att kollapsa på grund av den allmänna svenska tabuiseringen av och tystnaden kring ras.

Sverige är officiellt ett icke-rasistiskt land som tar avstånd från det koloniala och "vetenskapliga" rastänkandet, och det är också ett land som tar avstånd från diskriminering av invandrare och minoriteter, men människor som inte är vita och inte direkt kan kännas igen som netniska svenskar» diskrimineras trots detta i vardagen på grundval av sitt icke-vita utseende. Vår studie bekräftar att diskriminering inte enbart kan förklaras i termer av föreställda eller faktiska skillnader i klass, etnicitet, språk eller religion. De historiskt förankrade och vetenskapligt producerade före-

6 För postkolonial feministisk forskning om likheterna och skillnaderna mellan ras och etnicitet respektive kön och genus, se bland annat Anthias \& Yuval-Davis (1992), Ahmed (2000) och Alcoff (2005). ställningarna om olika rasers inre och yttre egenskaper och beteenden, samt geografiska, demografiska och kulturella tillskrivningar och tillhörigheter, är nämligen vid sidan av den strukturella diskrimineringen högst levande i den svenska samtidsvardagen. Kategoriseringar och karaktäriseringar av människor som exempelvis "asiater" och "afrikaner" görs hela tiden i vardagliga möten och interaktioner, och även de som inte har en hemvist i de kontinenter som uttrycken implicerar inkluderas ändå enligt logiken att vissa kroppsliga markörer kopplas samman med specifika geografiska områden, som i sin tur kopplas samman med vissa etniska/rasliga egenskaper.

Vårt material visar vidare att begreppsparen ras och etnicitet, och praktikerna rasifiering och etnifiering som skapat och återskapar dessa, hela tiden går in i varandra. Detta indikerar att svenskheten fortfarande är intimt sammankopplad med vita kroppar, och att de som "bryter" denna somatiska norm ifrågasätts och diskrimineras. Det som skiljer adopterade från andra svenskar är inget annat än deras ickevita kroppar, och det är denna "detalj» som hela tiden görs signifikant genom skillnadsskapande praktiker i form av vardagliga rasifierings- och etnifieringsprocesser. Vi menar därför att det är nödvändigt för både forskare och praktiker att börja beakta den historiskt och kulturellt konstruerade kategorin ras för att förstå diskriminering på grund av ett annorlunda utseende i dagens Sverige, eftersom ras verkar som en diskriminerande social kategori och föreställning i den svenska samtidskulturen och vardagskontexten.

Tobias Hübinette \& Carina Tigervall: Erfarenheter av rasifiering hos adopterade... 


\section{Referenser}

Ahmed, Sarah (2000) Strange encounters: Embodied others in post-coloniality. London: Routledge.

Alcoff, Linda Martín (2005) Visible identities. Race, gender and the self. London: Oxford University Press.

Andersson, Roger \& Molina, Irene (2003) »Racialization and migration in urban segregation processes. Key issues for critical geographers». I Jan Öhman \& Kirsten Simonsen (red.) Voices from the North. Aldershot: Ashgate.

Anthias, Floya \& Yuval-Davis, Nira (1992) Racialized boundaries. Race, nation, gender, colour, class and the anti-racist struggle. London: Routledge.

Bernhardtz, Lena \& Klintefelt, Annika (2007) „Det typiska adoptivbarnet». Välfärd vol. $7 \mathrm{nr} \mathrm{2,}$ s. 8-9.

von Borczyskowski Annika, Hjern Anders, Lindblad Frank \& Vinnerljung Bo (2006) "Suicidal behaviour in national and international adult adoptees". Social Psychiatry \& Psychiatric Epidemiologyvol. $41 \mathrm{nr}$ 2, s. 95-102.

Bråmå, Åsa (2006) „'White flight?' The production and reproduction of immigrant concentration areas in Swedish cities". Urban Studies vol. 43 nr 7, s. 1127-1146.

Burns Tom R., Machado Nora, Hellgren Zenia \& Bodin Göran (red.) (2007) Makt, kultur och kontroll över invandrares livsvillkor. Uppsala universitet: Sociologiska institutionen.

Carlberg, Margareta \& Nordin Jareno, Karin (red.) (2007) Internationellt adopterade i Sverige. Vad säger forskningen? Stockholm: Gothia.

Côté-Boucher, Karine (2008) „The diffuse border: Intelligence-sharing, control and confinement along Canada's smart border". Surveillance \& Society vol. $5 \mathrm{nr}$ 2, s. 142-165.

Essed, Philomena (1991) Understanding everyday racism. Newbury Park: Sage.

Hjern, Anders \& Allebeck, Peter (2002) "Suicide in first- and second-generation immigrants in Sweden". Social Psychiatry \& Psychiatric Epidemiology vol. $37 \mathrm{nr}$ 9, s. 423-429.
Hjern Anders, Lindblad Frank \& Vinnerljung Bo (2002) "Suicide, psychiatric illness, and social maladjustment in intercountry adoptees in Sweden". The Lancet vol. 360 nr 9331, s. 443448.

Hylland Eriksen, Thomas (1993) Etnicitet och nationalism. Nora: Nya Doxa

Hällgren, Camilla (2005) „'Working harder to be the same': Everyday racism among young men and women in Sweden". Race, Ethnicity \& Education vol. $8 \mathrm{nr}$ 3, s. 319-342.

Kalonaityté Viktorija, Kawesa Victoria \& Tedros Adiam (2007) Upplevelser av diskriminering och rasism bland ungdomar med afrikansk bakgrund i Sverige. Stockholm: Ombudsmannen mot etnisk diskriminering.

Kamali, Masoud (2005) Sverige inifrån. Röster om etnisk diskriminering. SOU 2005:69. Stockholm: Fritzes.

Lange, Anders \& Westin, Charles (1981) Etnisk diskriminering och social identitet. Stockholm: Publica \& Liber.

Lindblad Frank, Hjern Anders \& Vinnerljung Bo (2003) «Intercountry adopted children as young adults". American Journal of Orthopsychiatry vol. $73 \mathrm{nr} 2$, s. 190-202.

Lundström, Catrin (2007) Svenska latinas. Ras, klass och kön i svenskhetens geografi. Göteborg: Makadam.

Mattsson, Katarina \& Tesfahuney, Mekonnen (2002) „Rasism i vardagen«. I Ingemar Lindberg \& Magnus Dahlstedt (red.) Det slutna folkhemmet. Etniska klyftor och blågul självbild. Stockholm: Agora.

Miles, Robert (1989) Racism. London: Routledge.

Molina, Irene (1997) Stadens rasifiering: Etnisk boendesegregation i folkhemmet. Uppsala: Uppsala universitet, Kulturgeografiska institutionen.

Molina, Irene (2005) „Rasifiering». I Paulina de los Reyes \& Masoud Kamali (red.) Bortom Vi och Dom. Teoretiska reflektioner om makt, integration och strukturell diskriminering. SOU 2005:41. Stockholm: Fritzes.

Motsieloa, Viveca (2003) "Det måste vara någon- 
ting annat". En studie om barns upplevelser av rasism i vardagen. Stockholm: Rädda barnen.

Olsson, Erik (red.) (1999) Etnicitetens gränser och mångfald. Stockholm: Carlssons.

Omi, Michael \& Winant, Howard (1994) Racial formation in the United States. New York: Routledge.

Reuterberg, Sven-Eric \& Hansen, Michael (2001) Vilken betydelse har utländsk bakgrund för resultatet på högskoleprovet? Stockholm: Högskoleverket.

de los Reyes Paulina, Molina Irene \& Mulinari Diana (red.) (2002) Maktens (o) lika förklädnader. Kön, klass och etnicitet $i$ det postkoloniala Sverige. Stockholm: Atlas.

de los Reyes, Paulina \& Wingborg, Mats (2002) Vardagsdiskriminering och rasism. Norrköping: Integrationsverket.

Rooth, Dan-Olof (2001) „Etnisk diskriminering och 'Sverige-speficik' kunskap - vad vi kan lära från studier av adopterade och andra generationens invandrare». Ekonomisk Debatt vol. 29 nr 8, s. 535-546.

Rooth, Dan-Olof (2002) "Adopted children in the labour market - discrimination or unobserved characteristics? «. International Migration vol. $40 \mathrm{nr}$ 1, s. 71-98.

Runfors, Ann (2003) Mångfald, motsägelser och marginaliseringar. En studie av hur invandrarskap formas i skolan. Stockholm: Prisma.

Sawyer, Lena (2000) Black and Swedish: Racialization and the cultural politics of belonging in Stockholm, Sweden. Michigan: University of Michigan, Department of Cultural Anthropology.

Schmauch, Ulrika (2006) Den osynliga vardagsrasismens realitet. Umeå: Umeå universitet, Sociologiska institutionen.

Signell, Sonja \& Lindblad, Frank (2006/07) „Vad betyder asiatiskt utseende i Sverige?». Skolhälsovaird vol. $17 \mathrm{nr}$ 1, s. 17-19.

SOU 2005:56 Det blågula glashuset - strukturell diskriminering i Sverige. Betänkande av Utredningen mot strukturell diskriminering på grund av etnisk och religiös tillhörighet. Stockholm: Fritzes.

SOU 2006:79 Integrationens svarta bok. Agenda för jämlikhet och social sammanhållning. Betänkande av Utredningen om makt, integration och strukturell diskriminering. Stockholm: Fritzes.

Westin, Charles (1999) Mångfald, integration, rasism och andra ord. Stockholm: Socialstyrelsen.

Österberg, Torun (2000) Economic perspectives on immigrants and intergenerational transmissions. Göteborg: Göteborgs universitet, Nationalekonomiska institutionen.

Tobias Hübinette \& Carina Tigervall: Erfarenheter av rasifiering hos adopterade... 


\section{Summary}

\section{Experiences of racialization in adoptees and adoptive parents On the significance of a non-white appearance in Swedish everydaylife}

Recently, quantitative adoption research has found a high preponderance of psychic ill health among adult transnational and transracial adoptees in Sweden. This article introduces a research project inspired by critical race and whiteness studies, and based on interviews with 20 adult adoptees and 8 adoptive parents regarding their experiences of racialization. The article shows that the non-white bodies of the adoptees are constantly made significant in their everyday lives in interactions with the white Swedish majority population, whether expressed as "curious questions" about the ethnic origin of the adoptees or as outright aggressive racialization. Finally, the article argues that the race factor has to be taken into consideration by Swedish adoption research and the Swedish adoption community, to be able to fully grasp the specific and vulnerable situation of adult adoptees as found by quantitative adoption studies. The article also argues that race as a concept and as a category should be a part of Swedish migration and ethnicity studies to be able to understand the phenomenon of everyday racism, and the contemporary racial formations of Sweden, whereby a non-white appearance is increasingly being used to differentiate between "Swedes» and "non-Swedes". 